\title{
Sarcopenia, Obesity, and Sarcopenic Obesity: Relationship with Skeletal Muscle Phenotypes and Single Nucleotide Polymorphisms
}

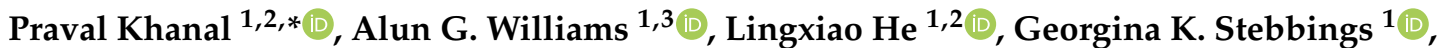

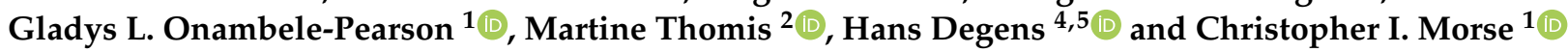

1 Musculoskeletal Science and Sports Medicine Research Centre, Department of Sport and Exercise Sciences, Manchester Metropolitan University Institute of Sport, Manchester Metropolitan University, Manchester M15 6BH, UK; a.g.williams@mmu.ac.uk (A.G.W.); lingxiao.he@hotmail.com (L.H.); G.Stebbings@mmu.ac.uk (G.K.S.); G.Pearson@mmu.ac.uk (G.L.O.-P.); c.morse@mmu.ac.uk (C.I.M.)

2 Physical Activity, Sports \& Health Research Group, Department of Movement Sciences, KU Leuven, 3001 Leuven, Belgium; martine.thomis@kuleuven.be

3 Institute of Sport, Exercise and Health, University College London, London W1T 7HA, UK

4 Musculoskeletal Science and Sports Medicine Research Centre, Department of Life Sciences, Manchester Metropolitan University Institute of Sport, Manchester Metropolitan University, Manchester M15 6BH, UK; h.degens@mmu.ac.uk

5 Institute of Sport Science and Innovations, Lithuanian Sports University, LT-44221 Kaunas, Lithuania

* Correspondence: praval.khanal@gmail.com

Citation: Khanal, P.; Williams, A.G.; He, L.; Stebbings, G.K.; OnambelePearson, G.L.; Thomis, M.; Degens, H.; Morse, C.I. Sarcopenia, Obesity, and Sarcopenic Obesity: Relationship with Skeletal Muscle Phenotypes and Single Nucleotide Polymorphisms. J. Clin. Med. 2021, 10, 4933. https://doi.org/10.3390/ jcm10214933

Academic Editors: Jamie McPhee and Napoleon Perez-Farinos

Received: 9 August 2021

Accepted: 19 October 2021

Published: 25 October 2021

Publisher's Note: MDPI stays neutral with regard to jurisdictional claims in published maps and institutional affiliations.

Copyright: (c) 2021 by the authors. Licensee MDPI, Basel, Switzerland. This article is an open access article distributed under the terms and conditions of the Creative Commons Attribution (CC BY) license (https:/ / creativecommons.org/licenses/by/ $4.0 /)$.
Abstract: Obesity may aggravate the effects of sarcopenia on skeletal muscle structure and function in the elderly, but no study has attempted to identify the gene variants associated with sarcopenia in obese women. Therefore, the aims of the present study were to: (1) describe neuromuscular function in sarcopenic and non-sarcopenic women with or without obesity; (2) identify gene variants associated with sarcopenia in older obese women. In 307 Caucasian women $(71 \pm 6$ years, $66.3 \pm 11.3 \mathrm{~kg})$, skeletal muscle mass was estimated using bioelectric impedance, and function was tested with a $30 \mathrm{~s}$ one-leg standing-balance test. Biceps brachii thickness and vastus lateralis cross-sectional area $\left(\mathrm{VL}_{\mathrm{ACSA}}\right)$ were measured with B-mode ultrasonography. Handgrip strength, maximum voluntary contraction elbow flexion $\left(\mathrm{MVC}_{\mathrm{EF}}\right)$, and knee extension torque $\left(\mathrm{MVC}_{\mathrm{KE}}\right)$ were measured by dynamometry, and $\mathrm{MVC}_{\mathrm{KE}} / \mathrm{VL}_{\mathrm{ACSA}}$ was calculated. Genotyping was performed for 24 singlenucleotide polymorphisms (SNPs), selected based on their previous associations with muscle-related phenotypes. Based on sarcopenia and obesity thresholds, groups were classified as sarcopenic obese, non-sarcopenic obese, sarcopenic non-obese, or non-sarcopenic non-obese. A two-way analysis of covariance was used to assess the main effects of sarcopenia and obesity on muscle-related phenotypes and binary logistic regression was performed for each SNP to investigate associations with sarcopenia in obesity. There were no significant obesity * sarcopenic status interactions for any of the investigated muscle-related phenotypic parameters. Neither sarcopenia nor obesity had a significant effect on biceps brachii thickness, but sarcopenia was associated with lower $\operatorname{VL}_{\mathrm{ACSA}}(p=0.003)$. Obesity was associated with lower $\operatorname{MVC}_{\mathrm{EF}}(p=0.032), \mathrm{MVC}_{\mathrm{KE}}(p=0.047)$, and $\mathrm{MVC}_{\mathrm{KE}} / \mathrm{VL}_{\mathrm{ACSA}}$ $(p=0.012)$ with no significant effect of sarcopenia. Adjusted for age and height, three SNPs (ACTN3 rs1815739, MTHFR rs1801131, and MTHFR rs1537516) were associated with sarcopenia in obese participants. Sarcopenia was associated with a smaller muscle size, while obesity resulted in a lower muscle quality irrespective of sarcopenia. Three gene variants (ACTN3 rs1815739, MTHFR rs1801131, and MTHFR rs1537516) suspected to affect muscle function, homocysteine metabolism, or DNA methylation, respectively, were associated with sarcopenia in obese elderly women. Understanding the skeletal muscle features affected by sarcopenia and obesity, and identification of genes related to sarcopenia in obese women, may facilitate early detection of individuals at particular risk of sarcopenic obesity.

Keywords: elderly; sarcopenic obese; neuromuscular; single-nucleotide polymorphisms 


\section{Introduction}

Ageing is associated with an increase in visceral and intramuscular fat [1] and a decrease in skeletal muscle mass [2]. The co-existence of low muscle mass and higher fat is termed sarcopenic obesity (SO) [3], a condition that is most prevalent in the older populations [4], particularly in women [5]. Sarcopenia and obesity are interlinked and share some common pathophysiology. For instance, both are related to hormonal alteration, low physical activity, elevated oxidative stress and pro-inflammatory cytokines, and insulin resistance [6]. It has been suggested that the synergistic effect of sarcopenia and obesity in SO exacerbates the condition compared to sarcopenia or obesity alone $[7,8]$. This has been evidenced through the higher all-cause mortality in $\mathrm{SO}$ than sarcopenia or obesity alone in men [9] and the aggravated detrimental effect on physical performance [10].

The prevalence of SO can range from 3.6 to $94.0 \%$ in the same population of elderly women depending on the applied sarcopenia and obesity thresholds/indices [11], an issue that plagues many study definitions [12]. Lower handgrip strength (HGS) is an initial confirming diagnosis of sarcopenia [13]. SO studies that define sarcopenia through lower HGS and muscle mass show a better prediction of physical capacity/functional status in an elderly population [14-17], compared to studies using a lower muscle mass threshold alone [18-21]. Similarly, in the context of obesity identification, the threshold of percentage body fat (BF\%) may be more valid than body mass index (BMI) as BMI may not change noticeably in some cases, despite a significant change in muscle and fat mass with ageing [22]. Therefore, the inclusion of thresholds for lower muscle strength together with lower muscle mass to detect sarcopenia, and use of percentage of adiposity in obesity classifications, may best distinguish between non-sarcopenic non-obese, sarcopenic, obese, and SO older people [23,24]. Despite the inconsistency in SO definitions, $\mathrm{SO}$ has been associated with limitations to perform activities of daily living [3], metabolic disorders [25], cardiovascular diseases (CVDs) [9], physical performance [26] impaired pulmonary function [27], and increased risk of all-cause mortality [28].

In the elderly, impairments in neuromuscular function are likely dependent on the severity of muscle wasting and obesity. For instance, the impact of loss of muscle mass on muscle function is well established [29,30], and similarly obesity is known to impact neuromuscular function negatively in the elderly [31,32]. The fact that some elderly people are $\mathrm{SO}$ while others are not suggests that $\mathrm{SO}$ is the consequence of the interplay between factors that influence both muscle and obesity related phenotypes, such as physical activity, diet, sedentary behavior, and genetics [33-35]. Several studies have associated singlenucleotide polymorphisms (SNPs) with muscle mass and strength in the elderly [36,37], and recently our group found that sarcopenia in elderly women was associated with polymorphisms in FTO, TRHR, ESR1, and NOS3 [38]. Similarly, adiposity and obesity measures have been associated to SNPs such as FTO and PPARG2 in the elderly [39]. Yet, the interrelation of SNPs and SO has not been investigated. Since sarcopenia and obesity each have been associated with adverse outcome measures in the elderly [40,41], an assessment of the modulating role of gene variants should include sarcopenia and obesity groups alongside an $\mathrm{SO}$ group. The aim of the present study was therefore to: (1) describe neuromuscular function in sarcopenic and non-sarcopenic women with or without obesity, and (2) identify gene variants associated with sarcopenia in obese elderly women.

\section{Methodology}

\subsection{Participants}

Elderly women ( $n=307$, aged $71 \pm 6$ years) were recruited from community groups in England, such as the University of Third Age (U3A) and from word-of-mouth contacts. The participants were 60+ years, free from any issues that affected their daily activities and physical independence, and had no known neuromuscular or cardiovascular disorders. Informed consent was collected from participants. Study protocols for the project followed the Declaration of Helsinki guidelines and were approved by the ethics committee of Manchester Metropolitan University. 


\subsection{Procedures}

Procedures for body composition, muscle size, functional tests, and genotyping are described in detail elsewhere [38,42], with a brief overview provided below.

\subsection{Body Composition and Muscle Size}

Bio-impedance analysis (Bodystat 1500MDD, Isle of Man, UK) was used to estimate the skeletal muscle mass (SMM) and $\mathrm{BF} \%$ of the participants [38]. Adhesive electrodes were connected to the dorsum of the right hand and leg with participants in a supine position. SMM was estimated with a previously validated equation [43] and BF\% was recorded. Skeletal muscle index (SMI) was calculated as SMM/height ${ }^{2}$ where height is in $\mathrm{m}$.

Biceps brachii thickness was measured by ultrasound (MyLab ${ }^{\mathrm{TM}}$ Twice, Esaote Biomedical, Genoa, Italy). In short, the participants were asked to relax and hang their dominant arm at their side and then the sagittal plane ultrasound scan was performed at $60 \%$ length from the proximal end of the humerus [44]. Mean muscle thickness was measured with digitizing software (Image 1.45, National Institute of Health, Bethesda, MD, USA) at three sites [45] (proximal, middle, and distal ends of the captured image) and recorded as biceps brachii thickness.

To assess the anatomical cross-sectional area of the vastus lateralis muscle $\left(\mathrm{VL}_{\mathrm{ACSA}}\right)$, the same ultrasound was used to scan in a transverse plane at $50 \%$ of VL length. During the procedure, the ultrasound probe was moved gently over the echo-absorptive markers (placed from medial to lateral border of muscle) with minimal pressure applied, and the scan was recorded as a video file. The recorded video was split into different individual images, and the entire $\mathrm{VL}_{\mathrm{ACSA}}$ was reconstructed by combining the individual images between the contiguous intervals between each shadow cast by markers. For the measurement, digitizing software (ImageJ 1.45, National Institute of Health, Bethesda, MD, USA) was used to draw around the visible aponeurosis of the reconstructed VL to estimate ACSA. The reliability and validity of this method were previously reported as high (ICC > 0.99) when compared with MRI [46].

\subsection{Muscle Strength and Quality Measurement}

Handgrip strength (HGS) was measured for both the right and left hands with a dynamometer (JAMAR plus, JLW Instruments, Chicago, IL, USA). Three trials were performed with each hand and the highest value from either hand was recorded [38]. The ICC of HGS with this procedure is 0.99 [47].

For the measurement of maximum voluntary contraction elbow flexion torque ( $\left.\mathrm{MVC}_{\mathrm{EF}}\right)$ and maximum voluntary contraction knee extension torque $\left(\mathrm{MVC}_{\mathrm{KE}}\right)$, a customized dynamometer with a load cell (Zemic, Eten-Leur, the Netherlands) was used. Both procedures were performed on the participant's dominant side, identified by self-report. $\mathrm{MVC}_{\mathrm{EF}}$ was performed at $60^{\circ}$ flexion ( $0^{\circ}$ is a straight position). Three trials were performed and the maximum of the three attempts was recorded and converted to $\mathrm{MVC}_{\mathrm{EF}}$ torque as:

$$
\mathrm{MVC}_{\mathrm{EF}}=\text { Force } \times \text { Radius length } \times \operatorname{Cos} 30^{\circ}
$$

Similarly, three trials were used to assess $\mathrm{MVC}_{\mathrm{KE}}$ at $120^{\circ}$ knee extension $\left(180^{\circ}\right.$ is a full knee extension) with $\mathrm{MVC}_{\mathrm{KE}}$ torque calculated from the highest value as:

$\mathrm{MVC}_{\mathrm{KE}}=$ Force $\times($ distance from rotation point of dynamometer to ankle strap $) \times \operatorname{Cos} 30^{\circ}$

Subsequently, lower-limb muscle quality was defined as the knee strength relative to $\mathrm{VL}_{\mathrm{ACSA}}\left(\mathrm{MVC}_{\mathrm{KE}} / \mathrm{VL}_{\mathrm{ACSA}}\right)$.

\subsection{One-Leg Standing-Balance Test}

As a measure of balance and for the purposes of classifying participants (see statistics part below), the one-leg standing-balance test (OLST) was performed barefoot on the right leg regardless of dominance, consistent with previous studies $[48,49]$. Participants were 
instructed to stand straight, with their left knee flexed at $\sim 90^{\circ}$, for up to a maximum of $30 \mathrm{~s}$. Participants completed up to three attempts if they failed to achieve $30 \mathrm{~s}$, and the maximum time achieved was recorded as their OLST score [50].

\subsection{Selection of Single-nucleotide Polymorphisms, Sample Collection, DNA Extraction and Genotyping}

A total of 24 SNPs were selected for the present study (Supplementary Table S1) based on a number of reasons, including the presence of extant literature associating those SNPs with similar phenotypes (even if in different populations), and the likelihood of affecting relevant muscle phenotypes via transcriptional differences as reported in previous studies. Some SNPs were also included due to conflicting results regarding associations with relevant phenotypes.

Blood or saliva samples were collected for genetic analysis. A QIAcube robot, QIAamp DNA Blood Mini kit, and standard spin column protocol (Qiagen, Crawley, UK) were used to isolate DNA from the collected samples. A Fluidigm EP1 system (Fluidigm, Cambridge, UK) was used for initial genotyping of the 24 SNPs. When there was an error (such as no agreement between duplicates), a StepOnePlus (Applied Biosystems ${ }^{\circledR}$, Paisley, UK) was later used. The PCR conditions using the EP1 followed the manufacturer's instructions. In short, the thermocycling protocol was an initial $120 \mathrm{~s}$ at $95{ }^{\circ} \mathrm{C}$ followed by 45 cycles of denaturation for $2 \mathrm{~s}$ at $95^{\circ} \mathrm{C}$ and then annealing and extension for $20 \mathrm{~s}$ at $60{ }^{\circ} \mathrm{C}$. Genotypes were identified based on end-point fluorescence, whereby TaqMan assays (Applied Biosystems, Paisley, UK) included VIC ${ }^{\circledR}$ and FAM ${ }^{\circledR}$ dyes for all SNPs. Similarly, for the StepOnePlus, the thermocycling conditions were an initial $20 \mathrm{~s}$ at $95{ }^{\circ} \mathrm{C}$ followed by 50 cycles of denaturation for $3 \mathrm{~s}$ at $95^{\circ} \mathrm{C}$, then annealing and extension for $20 \mathrm{~s}$ at $60{ }^{\circ} \mathrm{C}$. Genotyping and interpretation were based on intensity of $\mathrm{VIC}^{\circledR}$ and FAM $^{\circledR}$ intensity and visualization was performed using cluster plots.

\section{Statistics}

SPSS 26.0 (SPSS, Chicago, IL, USA) was used for all analyses. Participants were characterized into four non-overlapping groups based on thresholds for sarcopenia and obesity. Sarcopenia was defined as an SMI $<6.76 \mathrm{~kg} / \mathrm{m}^{2}$ [51] and lower HGS as suggested by EWGSOP [52]. Receiver operating curve (ROC) analysis was performed to determine the sarcopenic threshold for lower HGS based on an OLST balance of $<5 \mathrm{~s}$ [53]. This resulted in a good classification (AUC $=0.80$ ) of lower HGS with OLST and identified the HGS threshold of $28.35 \mathrm{~kg}$ ( $\sim 28.5 \mathrm{~kg}$ ) (sensitivity $65 \%$, specificity $82 \%$ ) as a measure of low muscle strength. Obesity was defined as BF\% > 38\% [28].

Based on the above thresholds for sarcopenia and obesity, SO individuals were defined as those with SMI $<6.76 \mathrm{~kg} / \mathrm{m}^{2}$, HGS $<28.5 \mathrm{~kg}$ and $\mathrm{BF} \%>38 \%$. Non-sarcopenic obese were defined as individuals who were non-sarcopenic (either SMI $\geq 6.76 \mathrm{~kg} / \mathrm{m}^{2}$ or HGS $>28.5 \mathrm{~kg}$ or both) but had $\mathrm{BF} \%>38 \%$. Sarcopenic non-obese were defined as individuals who were sarcopenic (SMI $<6.76 \mathrm{~kg} / \mathrm{m}^{2}$ and $\mathrm{HGS}<28.5 \mathrm{~kg}$ ) and had BF\% $\leq 38 \%$. The non-sarcopenic non-obese group was defined as individuals who were non-sarcopenic (either SMI $\geq 6.76 \mathrm{~kg} / \mathrm{m}^{2}$ or HGS $>28.5 \mathrm{~kg}$ or both) and had $\mathrm{BF} \% \leq 38 \%$. The classification of participants into four groups is shown in Figure 1 and adopted an approach used previously $[5,18,54]$.

A Shapiro-Wilk test was performed to test whether the data were normally distributed. Variables that were not normally distributed (biceps brachii thickness, $\mathrm{MVC}_{\mathrm{EF}}$, and $\mathrm{MVC}_{\mathrm{KE}} / \mathrm{VL}_{\mathrm{ACSA}}$ ) were log-transformed before further statistical analysis. To identify covariates, Pearson correlation coefficients were calculated between age and height, and body composition indices (BF\% and SMI). A two-way analysis of covariance (ANCOVA) was used to assess the main effects of sarcopenia and obesity on muscle-related phenotypic outcome measures, where a sarcopenia * obesity interaction would indicate that the effects of sarcopenia differed between the obese and non-obese, or that the effect of obesity was different in sarcopenic and non-sarcopenic women. 


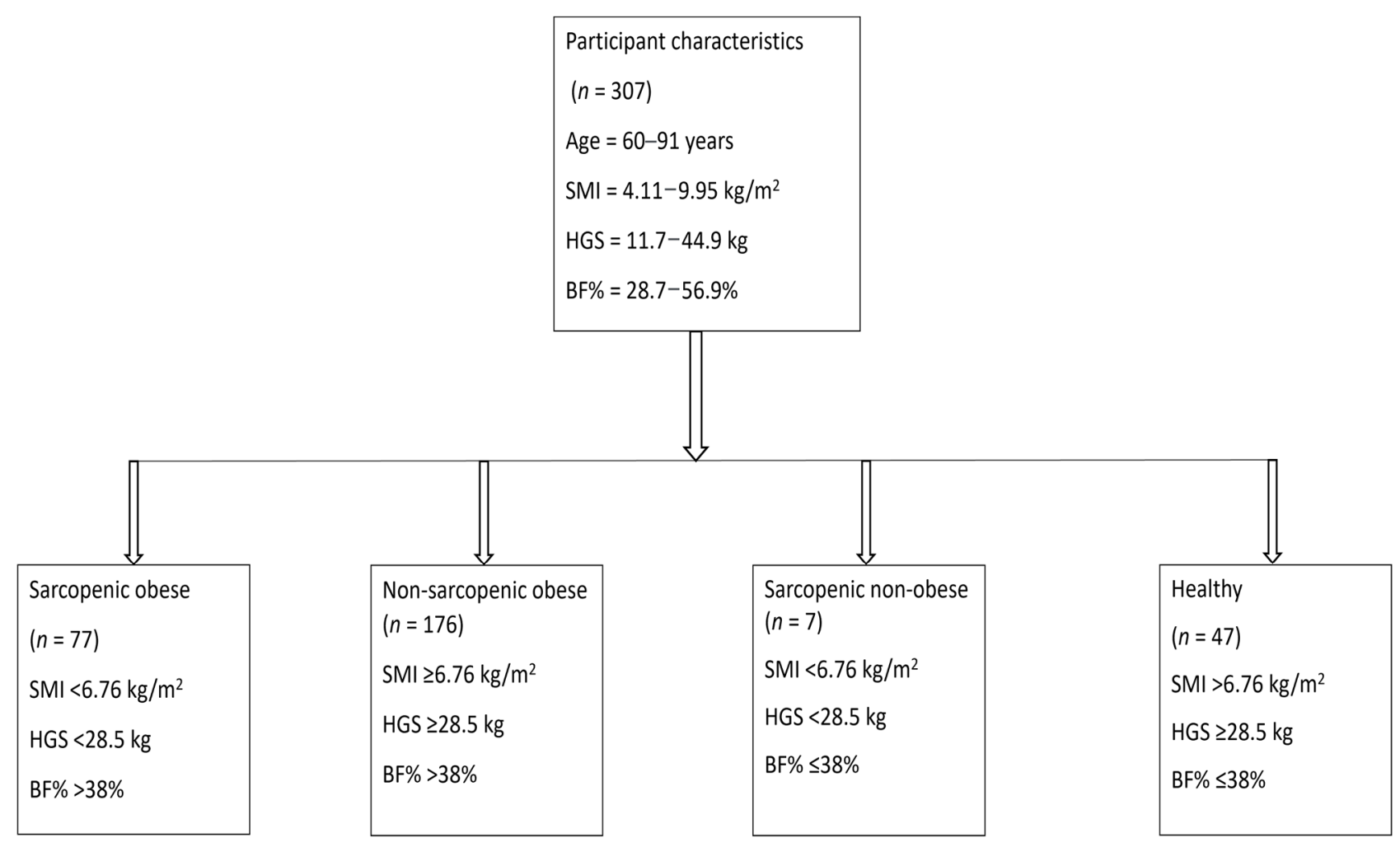

Figure 1. Flowchart showing the classification of participants into four categories: sarcopenic-obese, non-sarcopenic obese, sarcopenic non-obese, and non-sarcopenic non-obese groups. Abbreviations: SMI, skeletal muscle index; HGS, handgrip strength; $\mathrm{BF} \%$, body fat percent.

Binary logistic regression was performed for each individual SNP using the covariates to investigate their association with sarcopenia in the obese elderly. Where $p<0.15$, the rarer homozygotes were combined with heterozygotes (in both dominant and recessive models) and two-group analysis was performed. Similarly, when very few participants were in one of the homozygous groups, the group was combined with the heterozygotes [55]. Odds ratio (OR) was used to estimate effect size for significant SNP-groups associations. In all analyses, $p<0.05$ was considered significant. Only significant SNP associations are reported.

\section{Results}

4.1. General Characteristics, Prevalence, and Differences in Muscle Size, Strength, and Quality among Groups

The prevalence of sarcopenic-obese, non-sarcopenic obese, sarcopenic non-obese, and non-sarcopenic non-obese groups was $25.1 \%, 57.3 \%, 2.3 \%$, and $15.3 \%$, respectively, in the present elderly women. There were significant differences in age, height, body mass, BMI, SMI, HGS, OLST, and BF\% between the groups (Table 1).

There were significant correlations between $\mathrm{BF} \%$ and age $(\mathrm{r}=0.290, p<0.001)$, and $\mathrm{BF} \%$ and height $(\mathrm{r}=-0.250, p<0.001)$. Table 2 shows the data on muscle size and strength. There was no significant obesity * sarcopenic status interaction for any of the investigated muscle-related phenotypic parameters, indicating that the effect of sarcopenia did not differ according to obesity status, and that the effect of obesity did not differ according to sarcopenia status. There was no significant impact of obesity and sarcopenia on biceps brachii thickness $(p>0.05)$. Sarcopenia was associated with lower $\operatorname{VL}_{\text {ACSA }}(p=0.003)$, but there was no significant effect of obesity $(p=0.074)$. Obesity was associated with a lower $\operatorname{MVC}_{\mathrm{EF}}(p=0.032), \mathrm{MVC}_{\mathrm{KE}}(p=0.047)$, and $\mathrm{MVC}_{\mathrm{KE}} / \mathrm{VL}_{\mathrm{ACSA}}(p=0.012)$ with no significant effect of sarcopenia on these parameters $(p>0.05)$. 
Table 1. Physical, sarcopenic, and obesity-related characteristics among groups.

\begin{tabular}{|c|c|c|c|c|c|}
\hline Variables & $\begin{array}{c}\text { Overall } \\
\text { Characteristics } \\
(n=307)\end{array}$ & $\begin{array}{l}\text { Sarcopenic Obese } \\
\quad(n=77)\end{array}$ & $\begin{array}{c}\text { Non-Sarcopenic } \\
\text { Obese } \\
(n=176)\end{array}$ & $\begin{array}{c}\text { Sarcopenic } \\
\text { Non-Obese } \\
\quad(n=7)\end{array}$ & $\begin{array}{c}\text { Non-Sarcopenic } \\
\text { Non-Obese } \\
(n=47)\end{array}$ \\
\hline Age (years) & $70.7(70.1-71.4)$ & $72.5(71.3-73.8)^{4}$ & $70.8(70.0-71.7)^{4}$ & $68.7(65.2-72.2)$ & $67.6(66.3-69.0)^{1,2}$ \\
\hline Height (m) & $1.60(1.59-1.60)$ & $1.58(1.57-1.59)^{2,4}$ & $1.60(1.59-1.61)^{1}$ & $1.63(1.58-1.67)$ & $1.62(1.61-1.64)^{1}$ \\
\hline Body mass (kg) & $66.3(65.01-67.6)$ & $62.1(60.1-64.0)^{2}$ & $70.5(68.7-72.2)^{1,3,4}$ & $55.2(48.6-61.7)^{2}$ & $59.6(57.5-61.6)^{2}$ \\
\hline BMI $\left(\mathrm{kg} / \mathrm{m}^{2}\right)$ & $25.9(25.4-26.4)$ & $24.8(24.1-25.6)^{2,3,4}$ & $27.5(26.9-28.1)^{1,3,4}$ & $20.8(19.1-22.5)^{1,2}$ & $22.5(22.0-23.1)^{1,2}$ \\
\hline SMI $\left(\mathrm{kg} / \mathrm{m}^{2}\right)$ & $6.56(6.47-6.65)$ & $5.96(5.85-6.08)^{2,4}$ & $6.71(6.59-6.83)^{1}$ & $6.21(5.83-6.60)^{4}$ & $7.00(6.80-7.20)^{1,3}$ \\
\hline HGS (kg) & $29.9(29.3-30.5)$ & $25.3(24.7-25.9)^{2,4}$ & $31.0(30.3-31.7)^{1,3,4}$ & $25.8(23.6-28.0)^{2,4}$ & $34.0(32.7-35.2) 1,2,3$ \\
\hline OLST (s) & $23(22-24)$ & $20(18-23)^{2,4}$ & $23(22-25)^{1}$ & $22(14-30)$ & $29(28-30)^{1}$ \\
\hline $\mathrm{BF} \%$ & $42.6(42.1-43.2)$ & $44.4(43.5-45.3)^{3,4}$ & $44.1(43.5-44.7)^{3,4}$ & $36.1(34.6-37.7)^{1,2}$ & $35.0(34.5-35.6)^{1,2}$ \\
\hline
\end{tabular}

Abbreviations: BMI, body mass index; SMI, skeletal muscle mass index; HGS, handgrip strength; OLST, one-leg standing-balance test; $\mathrm{BF}$, body fat. 1,2,3,4 denote differences from sarcopenic-obese, non-sarcopenic obese, sarcopenic non-obese, and non-sarcopenic non-obese groups, respectively. Data are means $(95 \% \mathrm{CI})$.

Table 2. Muscle size, strength, and quality among groups (phenotype data are presented as means (95\% confidence intervals).

\begin{tabular}{|c|c|c|c|c|c|c|c|}
\hline Variables & $\begin{array}{c}\text { Sarcopenic } \\
\text { Obese } \\
(n=77)\end{array}$ & $\begin{array}{c}\text { Non- } \\
\text { Sarcopenic } \\
\text { Obese } \\
(n=176)\end{array}$ & $\begin{array}{c}\text { Sarcopenic } \\
\text { Non-Obese } \\
\quad(n=7)\end{array}$ & $\begin{array}{c}\text { Non- } \\
\text { Sarcopenic } \\
\text { Non-Obese } \\
(n=47)\end{array}$ & $\begin{array}{l}p \text {-Value } \\
\text { Obesity }\end{array}$ & $\begin{array}{c}p \text {-Value } \\
\text { Sarcopenia }\end{array}$ & $\begin{array}{c}p \text {-Value } \\
\text { Sarcopenia * } \\
\text { Obesity }\end{array}$ \\
\hline $\begin{array}{l}\text { Biceps brachii } \\
\text { thickness }(\mathrm{cm})\end{array}$ & $\begin{array}{c}1.66 \\
(1.59-1.74)\end{array}$ & $\begin{array}{c}1.81 \\
(1.76-1.86)\end{array}$ & $\begin{array}{c}1.78 \\
(1.51-2.05)\end{array}$ & $\begin{array}{c}1.68 \\
(1.62-1.75)\end{array}$ & 0.544 & 0.933 & 0.173 \\
\hline $\mathrm{VL}_{\mathrm{ACSA}}\left(\mathrm{cm}^{2}\right)$ & $\begin{array}{c}14.7 \\
(14.0-15.5)\end{array}$ & $\begin{array}{c}17.1 \\
(16.6-17.6)\end{array}$ & $\begin{array}{c}13.9 \\
(10.5-17.3)\end{array}$ & $\begin{array}{c}16.4 \\
(15.4-17.4)\end{array}$ & 0.074 & 0.003 & 0.861 \\
\hline $\mathrm{MVC}_{\mathrm{EF}}(\mathrm{N} \cdot \mathrm{m})$ & $\begin{array}{c}21.5 \\
(20.3-22.8)\end{array}$ & $\begin{array}{c}25.4 \\
(24.6-26.1)\end{array}$ & $\begin{array}{c}25.7 \\
(19.2-32.2)\end{array}$ & $\begin{array}{c}27.8 \\
(25.1-30.4)\end{array}$ & 0.032 & 0.083 & 0.251 \\
\hline $\mathrm{MVC}_{\mathrm{KE}}(\mathrm{N} \cdot \mathrm{m})$ & $\begin{array}{c}48.2 \\
(44.6-51.8)\end{array}$ & $\begin{array}{c}56.6 \\
(53.9-59.2)\end{array}$ & $\begin{array}{c}66.1 \\
(44.9-87.3)\end{array}$ & $\begin{array}{c}62.9 \\
(55.9-70.0)\end{array}$ & 0.047 & 0.498 & 0.252 \\
\hline $\begin{array}{c}\mathrm{MVC}_{\mathrm{KE}} / \mathrm{VL}_{\mathrm{ACSA}} \\
\left(\mathrm{N} \cdot \mathrm{m} / \mathrm{cm}^{2}\right)\end{array}$ & $\begin{array}{c}3.39 \\
(3.10-3.68)\end{array}$ & $\begin{array}{c}3.37 \\
(3.20-3.54)\end{array}$ & $\begin{array}{c}4.88 \\
(3.34-6.42)\end{array}$ & $\begin{array}{c}3.89 \\
(3.48-4.30)\end{array}$ & 0.012 & 0.077 & 0.156 \\
\hline
\end{tabular}

Abbreviations: $\mathrm{VL}_{\mathrm{ACSA}}$, vastus lateralis anatomical cross-sectional area; $\mathrm{MVC}_{\mathrm{EF}}$, maximum voluntary contraction elbow flexion torque; $\mathrm{MVC}_{\mathrm{KE}}$, maximum voluntary contraction knee extension torque. Data are means $(95 \% \mathrm{CI}) .{ }^{1,2,3,4}$ indicate difference from sarcopenic obese, non-sarcopenic obese, sarcopenic non-obese and non-sarcopenic non-obese, respectively at $p \leq 0.05 .{ }^{*}$, standard in statistical notation to denote interaction between the grouping variables.

\subsection{Associations of Gene Variants with Sarcopenia in Obese Elderly Women}

The genotyping success rate was $>99 \%$ in the obese subgroups $(n=77+176)$. All genotype distributions were in Hardy-Weinberg equilibrium $(p>0.05)$. Among the 24 SNPs, three were associated with sarcopenia: ACTN3 rs1815739, MTHFR rs1801131, and MTHFR rs1537516 (Table 3) in obese elderly. The genotype distribution of these three SNPs is shown in Supplementary Table S2.

Table 3. Association of single-nucleotide polymorphisms with sarcopenia in obese women.

\begin{tabular}{cccccccc}
\hline SNPs & B & S.E $(\beta)$ & Wald's $\chi^{\mathbf{2}}$ & $\mathbf{p}$ & OR & 95\% CI & Risk Genotypes \\
\hline ACTN3 rs1815739 & 0.612 & 0.294 & 4.341 & 0.037 & 1.84 & $1.04-3.28$ & CC \\
MTHFR rs1801131 & 0.614 & 0.291 & 4.470 & 0.034 & 1.85 & $1.05-3.27$ & GG + GT \\
MTHFR rs1537516 & 1.011 & 0.341 & 8.811 & 0.003 & 2.75 & $1.41-5.36$ & AA + AG \\
\hline
\end{tabular}

Binary logistic regression adjusted for age and height showed that ACTN3 rs1815739 CC homozygotes had 1.8 times the odds of being in the sarcopenic group than T-allele carriers $(\mathrm{OR}=1.84,95 \%$ confidence interval $[\mathrm{CI}]=1.04-3.28, p=0.037)$ in an obese population. MTHFR rs1801131 G-allele carriers had 1.9 times the odds of being sarcopenic than TT homozygotes $(\mathrm{OR}=1.85,95 \% \mathrm{CI}=1.05-3.27, p=0.034)$ among obese elderly. Similarly, 
MTHFR rs1537516 A-allele carriers had 2.8 times the odds of being sarcopenic than GG homozygotes $(\mathrm{OR}=2.75,95 \%$ CI 1.41-5.36, $p=0.003$, Table 3 ) in obese elderly women.

\section{Discussion}

The present study showed that sarcopenia was associated with lower-limb muscle atrophy, while obesity was associated with reduced upper/lower-limb muscle strengths. Obesity, but not sarcopenia, was associated with lower muscle quality. We also identified that within the 253 obese elderly women, there were three SNPs that were associated with sarcopenia, namely, ACTN3 rs1815739, MTHFR rs1801131, and MTHFR rs1537516. Expanding the knowledge of the impact of polymorphisms on skeletal muscle phenotypes during sarcopenia and obesity in elderly women may help in early identification of individuals at particular risk of sarcopenic obesity.

The $25 \%$ prevalence of SO observed in the present elderly population is consistent with other studies reporting SO prevalence across different populations $[27,28,56-58]$. However, it should be noted that, despite similar SO prevalence, studies have used different indices of sarcopenia and obesity classification, which can result in a prevalence of $\mathrm{SO}$ in a given population being $4 \%$ or even as high as $94 \%$ depending on the sarcopenia and obesity definitions/thresholds used [11]. The present study was the first to investigate the association of muscle size, strength, and quality measures in different groups, ranging from non-sarcopenic non-obese to sarcopenic obese. Although we did not observe any effect of sarcopenia and obesity on biceps brachii thickness in the present elderly women, sarcopenia was associated with lower $\mathrm{VL}_{\mathrm{ACSA}}$. This association of sarcopenia with lower $\mathrm{VL}_{\mathrm{ACSA}}$ reflects the muscle atrophy in terms of mass/size in sarcopenic individuals $[59,60]$. We observed in elderly women that obesity is associated with a reduction in upper-limb $\left(\mathrm{MVC}_{\mathrm{EF}}\right)$ and lower-limb $\left(\mathrm{MVC}_{\mathrm{KE}}\right)$ muscle strength. This is somewhat surprising as most studies report a higher muscle strength in obese [32,61]. We have no explanation for this unexpected finding, but we did see a lower $\mathrm{MVC}_{\mathrm{KE}} / \mathrm{VL}_{\mathrm{ACSA}}$ reflecting a lower muscle quality that has regularly been reported in obesity $[62,63]$ and has been suggested to be due to accumulation of intramuscular fat, impaired muscle activation [32], and systemic inflammation [32,64]. Our findings suggest that obesity causes a reduced muscle quality, even in non-sarcopenic older women. The reduction in muscle function has been previously associated with an increased risk of falls [65] and disability in activities of daily living [66].

Few studies have attempted to identify the genes associated with sarcopenia [38,67-69]. It should be noted that the SNPs showing associations in the present study (ACTN3 rs1815739, MTHFR rs1801131, and MTHFR rs1537516) are different from our previous study that identified associations of FTO, TRHR, ESR1, and NOS3 gene variants with sarcopenia [38]. A possible explanation is that the previous study used a different definition of sarcopenia [38]. The present study identified elderly women with obesity who were ACTN3 rs1815739 RR homozygotes to be at a nearly-2-fold higher risk of sarcopenia than X-allele carriers. This association is consistent with a previous study that observed female $>$ 75-year-old R-allele carriers had a 2.8-fold higher risk of sarcopenia [69], but differs from another study that reported XX as the risk genotype for sarcopenia in older men and women [70]. ACTN3 rs1815739 has been widely studied with skeletal muscle phenotypes in different populations, with varying results [71]. Although the ACTN3 $\mathrm{R}$ allele mostly favors better athletic (sprint) performance [72] and higher muscle mass and strength phenotypes [73], there are also studies that have reported the $\mathrm{X}$ allele as beneficial for fat-free mass in older people or peak power in non-athletic populations [74,75]. The putative effect of ACTN3 genotype has also shown different results at baseline and post training. For instance, $\mathrm{XX}$ homozygotes had greater knee extensor peak strength while the gain after the training was greater for RR homozygotes in women [75]. Despite this ACTN3 rs $1815739 \mathrm{X}$ where the arginine (position 577) is replaced by a premature stop codon, there is no evidence that the deficit of alpha-actinin directly causes muscle-related disease [76], although recent evidence suggests a potential modulating role [77]. Furthermore, ACTN3 $\mathrm{X}$ as a beneficial allele is also consistent with a previous association with longevity [78] and 
improved oxidative metabolism in ACTN3 knockout mice [79]. Thus, the relationships of ACTN3 rs1815739 with muscle performance and health-related phenotypes are complex and seem dependent on context including population type.

The current study was the first to find an association of MTHFR gene variants (rs1537516 and rs1801131) with risk factors for sarcopenia in obese elderly women. MTHFR rs1537516 A-allele carriers had a >2-fold higher risk than GG homozygotes. As MTHFR plays an important role in methylation and thus in epigenetic control [80], the association of rs1537516 with sarcopenia in an obese population may occur via post-transcriptional regulation. However, we urge future studies to investigate the functional relevance of this SNP with sarcopenia. The minor A allele has been previously observed as a risk factor for higher diastolic blood pressure [81]. Similarly, MTHFR rs1801131 G-allele carriers had a 1.8-fold higher risk of sarcopenia than TT homozygotes in our elderly female population. Although the GG genotype was advantageous for speed and strength performance in young Russian and Polish athletes [82], our observation may be explained by the association of the GG genotype with higher plasma homocysteine concentration [83]. Previous studies have associated elevated homocysteine with lower physical activity [84] and muscle strength [85]—characteristics observed in sarcopenic populations [52,86].

It is established that the degree and severity of sarcopenia and obesity increases with age $[13,87]$, despite individual differences related to favorable gene variants as well as dietary or exercise habits. Unlike research into athletic performance, where age at the time of sampling does not affect analysis of associations with elite performance while young [88], comparable studies of the elderly may be affected by participant age due to additional associations with longevity and health status. Accordingly, we acknowledge that there was likely to be a selection bias in the current study as we recruited elderly women who were still the healthiest of those within the broader population living independently. However, we suspect that studying elderly women who are more impaired would only stress the extremes of our phenotypes, potentially exposing more and/or stronger genetic associations.

Although the use of an adiposity threshold for the categorization of obesity is commonly used $[23,24]$, the thresholds for sarcopenia are still debatable and responsible for population variance in prevalence $[38,89]$. In the present study, sarcopenia was defined by HGS and muscle mass cut-offs in line with EWGSOP [52]. We should however acknowledge that our novel approach to establishing a low HGS threshold adopted a functional threshold of OLST $<5 \mathrm{~s}$. In contrast to others who have used a gait speed threshold of $0.8 \mathrm{~m} / \mathrm{s}[90,91]$, we suggest our approach of using a standing balance threshold is also valid as it was able to make a good prediction for HGS (AUC $=0.80$ ) with sensitivity of 65.0 and specificity of 82.0 , when compared with a previous study that showed sensitivity of 76.9 and specificity of 62.5 using gait speed threshold [90].

The current study has some other limitations. Firstly, participants were distributed unevenly between groups, meaning the sarcopenic non-obese group possessed few participants. This uneven group distribution could be overcome with a larger population group. Based on a power analysis for $\mathrm{MVC}_{\mathrm{EF}}$, we would need at least 21 people in a group to detect a $23.4 \%$ difference between groups with an $\alpha<0.05$ and a $\beta>0.80$. Our overall sample size would exceed $n=900$. Secondly, one needs to be cautious to extend our observations to men, as the current study is focused on elderly women, although it is likely that the action of most gene variants will not differ between men and women. Our decision to limit the investigation to a single sex can be justified by the earlier onset of sarcopenia-related problems with daily life in women than men [92]. The same argument applies to the fact that we only studied Caucasians, and findings may not be generalized to people with different geographic ancestry. We contend that this is a limitation of extrapolation of results, rather than a real limitation of method, as the genetic differences between people within a geographic ancestry group are larger than the typical genetic differences between geographic ancestry groups [93]. The current study used BIA for the estimation of skeletal muscle mass, a technique that is reported to overestimate skeletal 
muscle mass by $0.6 \mathrm{~kg}$ in the elderly [94]. Despite this shortcoming we used BIA as it is a cheap, accessible and radiation-free method that has been validated with DXA [95], and adopted on numerous occasions for large population studies of elderly muscle mass [96,97]. Finally, this investigation was limited to the 24 studied SNPs, and in fact it is likely that many other SNPs and other types of genetic variants, which we did not investigate, are also associated with the phenotypes we assessed.

\section{Conclusions}

Lower-limb muscle atrophy is a characteristic of sarcopenia, while obesity in older women was associated with lower upper- and lower-limb muscle strength. Three gene variants (ACTN3 rs1815739, MTHFR rs1801131, and MTHFR rs1537516) previously reported to affect muscle function, homocysteine metabolism, or suspected to affect DNA methylation, were associated with sarcopenia in obese elderly women. Understanding the neuromuscular features of sarcopenia and obesity and genes related to sarcopenia in obese elderly women may facilitate early detection of individuals at particular risk of sarcopenic obesity.

Supplementary Materials: The following are available online at https: / www.mdpi.com/article/ 10.3390/jcm10214933/s1, Table S1: Previous associations of single nucleotide polymorphisms with muscle-related phenotypes/performance, Table S2: Genotype distributions of SNPs associated with sarcopenia in obese elderly women.

Author Contributions: Conceptualization, P.K., A.G.W., G.K.S., G.L.O.-P., M.T., H.D. and C.I.M.; formal analysis, P.K., A.G.W. and C.I.M.; funding acquisition, A.G.W., G.K.S., G.L.O.-P., M.T., H.D. and C.I.M.; investigation, P.K., A.G.W., L.H. and C.I.M.; methodology, P.K., L.H., G.K.S., G.L.O.-P., M.T. and H.D.; supervision, A.G.W., G.K.S., G.L.O.-P., M.T., H.D. and C.I.M.; writing-original draft, P.K.; writing—review and editing, A.G.W., L.H., G.K.S., G.L.O.-P., M.T., H.D. and C.I.M. All authors have read and agreed to the published version of the manuscript.

Funding: This work was supported by the Erasmus Mundus Joint Doctorate program (2011-0015) funded by the European Union as a part of MOVE-AGE for Praval Khanal.

Institutional Review Board Statement: The study followed the 1964 Declaration of Helsinki guidelines and was approved by the local ethics committee (Manchester Metropolitan University Ethics Committee; Approval number: 09.02.16 (i)).

Informed Consent Statement: Informed consent was obtained from all participants involved in the study.

Data Availability Statement: The datasets generated during and/or analyzed during the present study are available from the corresponding author on reasonable request.

Conflicts of Interest: The authors declare no conflict of interest.

\section{References}

1. Michalakis, K.; Goulis, D.; Vazaiou, A.; Mintziori, G.; Polymeris, A.; Abrahamian-Michalakis, A. Obesity in the ageing man. Metabolism 2013, 62, 1341-1349. [CrossRef]

2. Nilwik, R.; Snijders, T.; Leenders, M.; Groen, B.B.; van Kranenburg, J.; Verdijk, L.; van Loon, L.J. The decline in skeletal muscle mass with aging is mainly attributed to a reduction in type II muscle fiber size. Exp. Gerontol. 2013, 48, 492-498. [CrossRef] [PubMed]

3. Baumgartner, R.N.; Wayne, S.J.; Waters, D.L.; Janssen, I.; Gallagher, D.; Morley, J.E. Sarcopenic Obesity Predicts Instrumental Activities of Daily Living Disability in the Elderly. Obes. Res. 2004, 12, 1995-2004. [CrossRef] [PubMed]

4. Zamboni, M.; Mazzali, G.; Fantin, F.; Rossi, A.; Di Francesco, V. Sarcopenic obesity: A new category of obesity in the elderly. Nutr. Metab. Cardiovasc. Dis. 2008, 18, 388-395. [CrossRef]

5. Chung, J.-Y.; Kang, H.-T.; Lee, D.C.; Lee, H.-R.; Lee, Y.-J. Body composition and its association with cardiometabolic risk factors in the elderly: A focus on sarcopenic obesity. Arch. Gerontol. Geriatr. 2013, 56, 270-278. [CrossRef] [PubMed]

6. Choi, K.M. Sarcopenia and sarcopenic obesity. Korean J. Intern. Med. 2016, 31, 1054. [CrossRef]

7. Wannamethee, S.G.; Atkins, J.L. Muscle loss and obesity: The health implications of sarcopenia and sarcopenic obesity. Proc. Nutr. Soc. 2015, 74, 405-412. [CrossRef] 
8. Kohara, K. Sarcopenic obesity in aging population: Current status and future directions for research. Endocrine 2014, 45, 15-25. [CrossRef]

9. Atkins, J.L.; Whincup, P.; Morris, R.; Lennon, L.; Papacosta, O.; Wannamethee, S. Sarcopenic Obesity and Risk of Cardiovascular Disease and Mortality: A Population-Based Cohort Study of Older Men. J. Am. Geriatr. Soc. 2014, 62, 253-260. [CrossRef]

10. Chang, C.-I.; Huang, K.-C.; Chan, D.-C.; Wu, C.-H.; Lin, C.-C.; Hsiung, C.A.; Hsu, C.-C.; Chen, C.-Y. The impacts of sarcopenia and obesity on physical performance in the elderly. Obes. Res. Clin. Pract. 2015, 9, 256-265. [CrossRef]

11. Batsis, J.A.; Barre, L.K.; Mackenzie, T.A.; Pratt, S.I.; Lopez-Jimenez, F.; Bartels, S.J. Variation in the Prevalence of Sarcopenia and Sarcopenic Obesity in Older Adults Associated with Different Research Definitions: Dual-Energy X-ray Absorptiometry Data from the National Health and Nutrition Examination Survey 1999-2004. J. Am. Geriatr. Soc. 2013, 61, 974-980. [CrossRef]

12. Prado, C.; Wells, J.; Smith, S.; Stephan, B.; Siervo, M. Sarcopenic obesity: A Critical appraisal of the current evidence. Clin. Nutr. 2012, 31, 583-601. [CrossRef] [PubMed]

13. Cruz-Jentoft, A.J.; Bahat, G.; Bauer, J.; Boirie, Y.; Bruyère, O.; Cederholm, T.; Cooper, C.; Landi, F.; Rolland, Y.; Sayer, A.A.; et al. Sarcopenia: Revised European consensus on definition and diagnosis. Age Ageing 2019, 48, 16-31. [CrossRef] [PubMed]

14. Öztürk, Z.A.; Türkbeyler, İ.H.; Abiyev, A.; Kul, S.; Edizer, B.; Yakaryılmaz, F.D.; Soylu, G. Health-related quality of life and fall risk associated with age-related body composition changes; sarcopenia, obesity and sarcopenic obesity. Intern. Med. J. 2018, 48, 973-981. [CrossRef]

15. Yoshimura, Y.; Wakabayashi, H.; Nagano, F.; Bise, T.; Shimazu, S.; Kudo, M.; Shiraishi, A. Sarcopenic Obesity Is Associated With Activities of Daily Living and Home Discharge in Post-Acute Rehabilitation. J. Am. Med. Dir. Assoc. 2020, 21, 1475-1480. [CrossRef] [PubMed]

16. Aibar-Almazán, A.; Martínez-Amat, A.; Díaz, D.C.; García, J.D.J.; Achalandabaso, A.; Sánchez-Montesinos, I.; de la Torre-Cruz, M.; Hita-Contreras, F. Sarcopenia and sarcopenic obesity in Spanish community-dwelling middle-aged and older women: Association with balance confidence, fear of falling and fall risk. Maturitas 2018, 107, 26-32. [CrossRef]

17. Huo, Y.R.; Suriyaarachchi, P.; Gomez, F.; Curcio, C.-L.; Boersma, D.; Gunawardene, P.; Demontiero, O.; Duque, G. Phenotype of sarcopenic obesity in older individuals with a history of falling. Arch. Gerontol. Geriatr. 2016, 65, 255-259. [CrossRef]

18. Rolland, Y.; Lauwers-Cances, V.; Cristini, C.; van Kan, G.A.; Janssen, I.; Morley, J.E.; Vellas, B. Difficulties with physical function associated with obesity, sarcopenia, and sarcopenic-obesity in community-dwelling elderly women: The EPIDOS (EPIDemiologie de l'OSteoporose) Study. Am. J. Clin. Nutr. 2009, 89, 1895-1900. [CrossRef]

19. Bouchard, D.R.; Dionne, I.J.; Brochu, M. Sarcopenic/obesity and physical capacity in older men and women: Data from the Nutrition as a Determinant of Successful Aging (NuAge)—The Quebec Longitudinal Study. Obesity 2009, 17, 2082-2088. [CrossRef]

20. Zoico, E.; Di Francesco, V.; Guralnik, J.M.; Mazzali, G.; Bortolani, A.; Guariento, S.; Sergi, G.; Bosello, O.; Zamboni, M. Physical disability and muscular strength in relation to obesity and different body composition indexes in a sample of healthy elderly women. Int. J. Obes. 2004, 28, 234-241. [CrossRef]

21. Scott, D.; Sanders, K.; Aitken, D.; Hayes, A.; Ebeling, P.R.; Jones, G. Sarcopenic obesity and dynapenic obesity: 5-year associations with falls risk in middle-aged and older adults. Obesity 2014, 22, 1568-1574. [CrossRef] [PubMed]

22. Kuk, J.L.; Saunders, T.; Davidson, L.; Ross, R. Age-related changes in total and regional fat distribution. Ageing Res. Rev. 2009, 8, 339-348. [CrossRef]

23. Atmis, V.; Yalcin, A.; Silay, K.; Ulutas, S.; Bahşi, R.; Turgut, T.; Sürmeli, D.M.; Öztorun, H.S.; Yaman, S.; Çoşarderelioğlu, Ç.; et al. The relationship between all-cause mortality sarcopenia and sarcopenic obesity among hospitalized older people. Aging Clin. Exp. Res. 2019, 31, 1563-1572. [CrossRef]

24. Kemmler, W.; Teschler, M.; Weißenfels, A.; Sieber, C.; Freiberger, E.; von Stengel, S. Prevalence of sarcopenia and sarcopenic obesity in older German men using recognized definitions: High accordance but low overlap! Osteoporos. Int. 2017, 28, 1881-1891. [CrossRef] [PubMed]

25. Lee, J.; Hong, Y.-P.; Shin, H.J.; Lee, W. Associations of Sarcopenia and Sarcopenic Obesity with Metabolic Syndrome Considering Both Muscle Mass and Muscle Strength. J. Prev. Med. Public Health 2016, 49, 35-44. [CrossRef]

26. Moreira, M.A.; Zunzunegui, M.V.; Vafaei, A.; Da Câmara, S.M.A.; Oliveira, T.S.; Maciel, C.C. Sarcopenic obesity and physical performance in middle aged women: A cross-sectional study in Northeast Brazil. BMC Public Health 2015, 16, 43. [CrossRef]

27. Oliveira, R.J.; Bottaro, M.; Júnior, J.T.; Farinatti, P.T.V.; Bezerra, L.A.; Lima, R.M. Identification of sarcopenic obesity in postmenopausal women: A cutoff proposal. Braz. J. Med. Biol. Res. 2011, 44, 1171-1176. [CrossRef]

28. Batsis, J.; Mackenzie, T.A.; Barre, L.K.; Lopez-Jimenez, F.; Bartels, S.J. Sarcopenia, sarcopenic obesity and mortality in older adults: Results from the National Health and Nutrition Examination Survey III. Eur. J. Clin. Nutr. 2014, 68, 1001-1007. [CrossRef] [PubMed]

29. Hairi, N.N.; Cumming, R.; Naganathan, V.; Handelsman, D.J.; Le Couteur, D.; Creasey, H.; Waite, L.M.; Seibel, M.J.; Sambrook, P.N Loss of Muscle Strength, Mass (Sarcopenia), and Quality (Specific Force) and Its Relationship with Functional Limitation and Physical Disability: The Concord Health and Ageing in Men Project. J. Am. Geriatr. Soc. 2010, 58, 2055-2062. [CrossRef]

30. Lauretani, F.; Russo, C.R.; Bandinelli, S.; Bartali, B.; Cavazzini, C.; Di Iorio, A.; Corsi, A.M.; Rantanen, T.; Guralnik, J.M.; Ferrucci, L. Age-associated changes in skeletal muscles and their effect on mobility: An operational diagnosis of sarcopenia. J. Appl. Physiol. 2003, 95, 1851-1860. [CrossRef] 
31. Tomlinson, D.J.; Erskine, R.; Winwood, K.; Morse, C.; Onambélé, G.L. The impact of obesity on skeletal muscle architecture in untrained young vs. old women. J. Anat. 2014, 225, 675-684. [CrossRef] [PubMed]

32. Tomlinson, D.J.; Erskine, R.; Morse, C.; Winwood, K.; Onambélé-Pearson, G. The impact of obesity on skeletal muscle strength and structure through adolescence to old age. Biogerontology 2016, 17, 467-483. [CrossRef] [PubMed]

33. Rondanelli, M.; Klersy, C.; Terracol, G.; Talluri, J.; Maugeri, R.; Guido, D.; A Faliva, M.; Solerte, B.S.; Fioravanti, M.; Lukaski, H.; et al. Whey protein, amino acids, and vitamin D supplementation with physical activity increases fat-free mass and strength, functionality, and quality of life and decreases inflammation in sarcopenic elderly. Am. J. Clin. Nutr. 2016, 103, 830-840. [CrossRef] [PubMed]

34. Fawcett, K.A.; Barroso, I. The genetics of obesity: FTO leads the way. Trends Genet. 2010, 26, 266-274. [CrossRef]

35. Santos, D.; Silva, A.; Baptista, F.; Santos, R.; Vale, S.; Mota, J.; Sardinha, L.B. Sedentary behavior and physical activity are independently related to functional fitness in older adults. Exp. Gerontol. 2012, 47, 908-912. [CrossRef] [PubMed]

36. Walsh, S.; Liu, D.; Metter, E.J.; Ferrucci, L.; Roth, S.M. ACTN3 genotype is associated with muscle phenotypes in women across the adult age span. J. Appl. Physiol. 2008, 105, 1486-1491. [CrossRef] [PubMed]

37. Charbonneau, D.E.; Hanson, E.D.; Ludlow, A.T.; Delmonico, M.J.; Hurley, B.F.; Roth, S.M. ACE Genotype and the Muscle Hypertrophic and Strength Responses to Strength Training. Med. Sci. Sports Exerc. 2008, 40, 677-683. [CrossRef]

38. Khanal, P.; He, L.; Stebbings, G.; Onambele-Pearson, G.L.; Degens, H.; Williams, A.; Thomis, M.; Morse, C.I. Prevalence and association of single nucleotide polymorphisms with sarcopenia in older women depends on definition. Sci. Rep. 2020, 10, 1-9. [CrossRef]

39. Galbete, C.; Toledo, J.; Martínez-González, M.; Martínez, J.A.; Guillén-Grima, F.; Marti, A. Lifestyle factors modify obesity risk linked to PPARG2 and FTO variants in an elderly population: A cross-sectional analysis in the SUN Project. Genes Nutr. 2013, 8, 61-67. [CrossRef]

40. Landi, F.; Cruz-Jentoft, A.J.; Liperoti, R.; Russo, A.; Giovannini, S.; Tosato, M.; Capoluongo, E.D.; Bernabei, R.; Onder, G. Sarcopenia and mortality risk in frail older persons aged 80 years and older: Results from ilSIRENTE study. Age Ageing 2013, 42, 203-209. [CrossRef]

41. De Stefano, F.; Zambon, S.; Giacometti, L.; Sergi, G.; Corti, M.C.; Manzato, E.; Busetto, L. Obesity, muscular strength, muscle composition and physical performance in an elderly population. J. Nutr. Health Aging 2015, 19, 785-791. [CrossRef] [PubMed]

42. Khanal, P.; He, L.; Degens, H.; Stebbings, G.K.; Onambele-Pearson, G.L.; Williams, A.G.; Thomis, M.; Morse, C.I. Dietary protein requirement threshold and micronutrients profile in healthy older women based on relative skeletal muscle mass. Nutrients 2021, 13, 3076. [CrossRef] [PubMed]

43. Janssen, I.; Heymsfield, S.B.; Baumgartner, R.N.; Ross, R. Estimation of skeletal muscle mass by bioelectrical impedance analysis. J. Appl. Physiol. 2000, 89, 465-471. [CrossRef] [PubMed]

44. Kanehisa, H.; Ito, M.; Kawakami, Y.; Fukunaga, T.; Miyatani, M. The accuracy of volume estimates using ultrasound muscle thickness measurements in different muscle groups. Eur. J. Appl. Physiol. 2004, 91, 264-272. [CrossRef] [PubMed]

45. Ogasawara, R.; Thiebaud, R.S.; Loenneke, J.P.; Loftin, M.; Abe, T. Time course for arm and chest muscle thickness changes following bench press training. Interv. Med. Appl. Sci. 2012, 4, 217-220. [CrossRef]

46. Reeves, N.D.; Maganaris, C.N.; Narici, M.V. Ultrasonographic assessment of human skeletal muscle size. Eur. J. Appl. Physiol. 2004, 91, 116-118. [CrossRef]

47. Villafañe, J.H.; Valdes, K.; Buraschi, R.; Martinelli, M.; Bissolotti, L.; Negrini, S. Reliability of the Handgrip Strength Test in Elderly Subjects with Parkinson Disease. HAND 2016, 11, 54-58. [CrossRef]

48. Gerbino, G.; Griffin, E.D.; Zurakowski, D. Comparison of standing balance between female collegiate dancers and soccer players. Gait Posture 2007, 26, 501-507. [CrossRef]

49. Gajdosik, R.L. Relation of age and passive properties of an ankle dorsiflexion stretch to the timed one-leg stance test in older women. Percept. Mot. Skills 2006, 103, 177-182. [CrossRef]

50. Bohannon, R.W.; Larkin, P.A.; Cook, A.C.; Gear, J.; Singer, J. Decrease in Timed Balance Test Scores with Aging. Phys. Ther. 1984, 64, 1067-1070. [CrossRef]

51. Janssen, I.; Baumgartner, R.N.; Ross, R.; Rosenberg, I.H.; Roubenoff, R. Skeletal Muscle Cutpoints Associated with Elevated Physical Disability Risk in Older Men and Women. Am. J. Epidemiol. 2004, 159, 413-421. [CrossRef] [PubMed]

52. Cruz-Jentoft, A.J.; Baeyens, J.P.; Bauer, J.M.; Boirie, Y.; Cederholm, T.; Landi, F.; Martin, F.C.; Michel, J.; Rolland, Y.; Schneider, S.M.; et al. Sarcopenia: European consensus on definition and diagnosisReport of the European Working Group on Sarcopenia in Older People. Age Ageing 2010, 39, 412-423. [CrossRef]

53. Michikawa, T.; Nishiwaki, Y.; Takebayashi, T.; Toyama, Y. One-leg standing test for elderly populations. J. Orthop. Sci. 2009, 14, 675-685. [CrossRef] [PubMed]

54. Monteiro, M.; Gabriel, R.; Aranha, J.; E Castro, M.N.; Sousa, M.; Moreira, H. Influence of obesity and sarcopenic obesity on plantar pressure of postmenopausal women. Clin. Biomech. 2010, 25, 461-467. [CrossRef]

55. Stebbings, G.K.; Williams, A.G.; Morse, C.I.; Day, S.H. Polymorphisms in PTK2 are associated with skeletal muscle specific force: An independent replication study. Eur. J. Appl. Physiol. 2017, 117, 713-720. [CrossRef] [PubMed]

56. Lim, H.-S.; Park, Y.-H.; Suh, K.; Yoo, M.H.; Park, H.K.; Kim, H.J.; Lee, J.-H.; Byun, D.-W. Association between Sarcopenia, Sarcopenic Obesity, and Chronic Disease in Korean Elderly. J. Bone Metab. 2018, 25, 187-193. [CrossRef] 
57. Oh, C.; Jho, S.; No, J.-K.; Kim, H.-S. Body composition changes were related to nutrient intakes in elderly men but elderly women had a higher prevalence of sarcopenic obesity in a population of Korean adults. Nutr. Res. 2015, 35, 1-6. [CrossRef]

58. Liu, L.-K.; Chen, L.-Y.; Yeh, K.-P.; Lin, M.-H.; Hwang, A.-C.; Peng, L.-N. Sarcopenia, but not sarcopenic obesity, predicts mortality for older old men: A 3-year prospective cohort study. J. Clin. Gerontol. Geriatr. 2014, 5, 42-46. [CrossRef]

59. Mitchell, W.K.; Williams, J.; Atherton, P.J.; Larvin, M.; Lund, J.N.; Narici, M. Sarcopenia, Dynapenia, and the Impact of Advancing Age on Human Skeletal Muscle Size and Strength; a Quantitative Review. Front. Physiol. 2012, 3, 260. [CrossRef]

60. de Bool, C.; Gosker, H.R.; den Borst, B.; den Kamp, C.M.O.; Slot, I.G.M.; Schols, A.M.W.J. Muscle quality is more impaired in sarcopenic patients with chronic obstructive pulmonary disease. J. Am. Med. Dir. Assoc. 2016, 17, 415-420. [CrossRef]

61. Abdelmoula, A.; Martin, V.; Bouchant, A.; Walrand, S.; Lavet, C.; Taillardat, M.; Maffiuletti, N.A.; Boisseau, N.; Duché, P.; Ratel, S. Knee extension strength in obese and nonobese male adolescents. Appl. Physiol. Nutr. Metab. 2012, 37, 269-275. [CrossRef] [PubMed]

62. Barbat-Artigas, S.; Rolland, Y.; Vellas, B.; Aubertin-Leheudre, M. Muscle Quantity Is Not Synonymous with Muscle Quality. J. Am. Med. Dir. Assoc. 2013, 14, 852.e1-852.e7. [CrossRef] [PubMed]

63. Lee, C.; Dierickx, E. Defining Sarcopenia Using Muscle Quality Index. J. Aging Res. Clin. Pract. 2018, 7, 45-59.

64. Tallis, J.; Shelley, S.; Degens, H.; Hill, C. Age-Related Skeletal Muscle Dysfunction Is Aggravated by Obesity: An Investigation of Contractile Function, Implications and Treatment. Biomolecules 2021, 11, 372. [CrossRef] [PubMed]

65. AhmadiAhangar, A.; Javadian, Y.; Babaei, M.; Heidari, B.; Hosseini, S.; Aminzadeh, M. The role of quadriceps muscle strength in the development of falls in the elderly people, a cross-sectional study. Chiropr. Man. Ther. 2018, 26, 1-6. [CrossRef]

66. Den Ouden, M.E.; Schuurmans, M.J.; Brand, J.S.; Arts, I.E.; Mueller-Schotte, S.; van der Schouw, Y.T. Physical functioning is related to both an impaired physical ability and ADL disability: A ten year follow-up study in middle-aged and older persons. Maturitas 2013, 74, 89-94. [CrossRef] [PubMed]

67. Roth, S.M.; Zmuda, J.M.; Cauley, J.A.; Shea, P.R.; Ferrell, R.E. Vitamin D receptor genotype is associated with fat-free mass and sarcopenia in elderly men. J. Gerontol. Ser. A Boil. Sci. Med. Sci. 2004, 59, B10-B15. [CrossRef]

68. Tasar, T. Retrospective Investigation of Interleukin 1 and 6 Gene Polymorphism among Elderly Patients with Sarcopenia in the Turkish Population. Genet. Mol. Res. 2018, 17, gmr16039881. [CrossRef]

69. Romero-Blanco, C.; González, M.J.A.; Gómez-Cabello, A.; Vila-Maldonado, S.; Casajús, J.A.; Ara, I.; Aznar, S. ACTN3 R577X polymorphism related to sarcopenia and physical fitness in active older women. Climacteric 2020, 24, 89-94. [CrossRef]

70. Cho, J.; Lee, I.; Kang, H. ACTN3 Gene and Susceptibility to Sarcopenia and Osteoporotic Status in Older Korean Adults. BioMed Res. Int. 2017, 2017, 1-8. [CrossRef] [PubMed]

71. Garatachea, N.; Lucia, A. Genes and the ageing muscle: A review on genetic association studies. Age 2013, 35, 207-233. [CrossRef] [PubMed]

72. Chen, W.; Zhang, B.; Li, Y.; Liang, T. Association Between rs1815739 Polymorphism of ACTN3 Gene and Athletic Ability in Chinese Sprinters. J. Sci. Sport Exerc. 2020, 2, 113-119. [CrossRef]

73. Kikuchi, N.; Nakazato, K.; Min, S.-K.; Ueda, D.; Igawa, S. The ACTN3 R577X Polymorphism Is Associated With Muscle Power in Male Japanese Athletes. J. Strength Cond. Res. 2014, 28, 1783-1789. [CrossRef] [PubMed]

74. Lima, R.M.; Leite, T.K.M.; Pereira, R.W.; Rabelo, H.T.; Roth, S.M.; Oliveira, R.J. ACE and ACTN3 genotypes in older women: Muscular phenotypes. Int. J. Sports Med. 2011, 32, 66. [CrossRef]

75. Delmonico, M.J.; Kostek, M.C.; Doldo, N.A.; Hand, B.D.; Walsh, S.; Conway, J.M.; Carignan, C.R.; Roth, S.; Hurley, B.F. AlphaActinin-3 (ACTN3) R577X Polymorphism Influences Knee Extensor Peak Power Response to Strength Training in Older Men and Women. J. Gerontol. Ser. A Boil. Sci. Med. Sci. 2007, 62, 206-212. [CrossRef]

76. North, K.N.; Yang, N.; Wattanasirichaigoon, D.; Mills, M.; Easteal, S.; Beggs, A. A common nonsense mutation results in $\alpha$-actinin-3 deficiency in the general population. Nat. Genet. 1999, 21, 353-354. [CrossRef]

77. Houweling, P.J.; Papadimitriou, I.D.; Seto, J.T.; Pérez, L.M.; del Coso, J.; North, K.N.; Lucia, A.; Eynon, N. Is evolutionary loss our gain? The role of ACTN3 Arg577Ter (R577X) genotype in athletic performance, ageing, and disease. Hum. Mutat. 2018, 39, 1774-1787. [CrossRef]

78. Fiuza-Luces, C.; Ruiz, J.R.; Rodríguez-Romo, G.; Santiago, C.; Gómez-Gallego, F.; Yvert, T.; Cano-Nieto, A.; Garatachea, N.; Morán, M.; Lucia, A. Are 'endurance'alleles 'survival'alleles? Insights from the ACTN3 R577X polymorphism. PLoS ONE 2011, 6, e17558. [CrossRef]

79. MacArthur, D.G.; Seto, J.T.; Chan, S.; Quinlan, K.G.R.; Raftery, J.M.; Turner, N.; Nicholson, M.D.; Kee, A.J.; Hardeman, E.C.; Gunning, P.W. An Actn3 knockout mouse provides mechanistic insights into the association between $\alpha$-actinin-3 deficiency and human athletic performance. Hum. Mol. Genet. 2008, 17, 1076-1086. [CrossRef]

80. García-Giménez, J.; Sanchis-Gomar, F.; Lippi, G.; Mena, S.; Ivars, D.; Gomez-Cabrera, M.C.; Viña, J.; Pallardó, F. Epigenetic biomarkers: A new perspective in laboratory diagnostics. Clin. Chim. Acta 2012, 413, 1576-1582. [CrossRef]

81. Moraes, A.C.F.; Fernández-Alvira, J.M.; Carvalho, H.B.; Meirhaeghe, A.; Dallongeville, J.; Kafatos, A.; Marcos, A.; Molnar, D.; Manios, Y.; Ruiz, J.R.; et al. Physical activity modifies the associations between genetic variants and blood pressure in European adolescents. J. Pediatr. 2014, 165, 1046-1049.e2. [CrossRef]

82. Zarebska, A.; Ahmetov, I.; Sawczyn, S.; Weiner, A.S.; Kaczmarczyk, M.; Ficek, K.; Maciejewska-Karlowska, A.; Sawczuk, M.; Leonska-Duniec, A.; Klocek, T.; et al. Association of the MTHFR 1298A > C (rs1801131) polymorphism with speed and strength sports in Russian and Polish athletes. J. Sports Sci. 2013, 32, 375-382. [CrossRef] [PubMed] 
83. Castro, R.; Rivera, I.; Ravasco, P.; E Camilo, M.; Jakobs, C.; Blom, H.; De Almeida, I.T. 5,10-methylenetetrahydrofolate reductase (MTHFR) $677 \mathrm{C} \rightarrow \mathrm{T}$ and 1298A $\rightarrow \mathrm{C}$ mutations are associated with DNA hypomethylation. J. Med. Genet. 2004, 41, 454-458. [CrossRef]

84. Dankner, R.; Chetrit, A.; Dror, G.K.; Sela, B.-A. Physical activity is inversely associated with total homocysteine levels, independent of C677T MTHFR genotype and plasma B vitamins. Age 2007, 29, 219-227. [CrossRef] [PubMed]

85. Kuo, H.-K.; Liao, K.-C.; Leveille, S.G.; Bean, J.F.; Yen, C.; Chen, J.; Yu, Y.; Tai, T. Relationship of homocysteine levels to quadriceps strength, gait speed, and late-life disability in older adults. J. Gerontol. Ser. A Biol. Sci. Med. Sci. 2007, 62, 434-439. [CrossRef]

86. Steffl, M.; Bohannon, R.W.; Sontakova, L.; Tufano, J.; Shiells, K.; Holmerova, I. Relationship between sarcopenia and physical activity in older people: A systematic review and meta-analysis. Clin. Interv. Aging 2017, 12, 835-845. [CrossRef]

87. Elia, M. Obesity in the elderly. Obes. Res. 2001, 9, 244S-248S. [CrossRef]

88. Heffernan, S.M.; Stebbings, G.K.; Kilduff, L.P.; Erskine, R.M.; Day, S.H.; Morse, C.I.; McPhee, J.S.; Cook, C.J.; Vance, B.; Ribbans, W.J.; et al. Fat mass and obesity associated (FTO) gene influences skeletal muscle phenotypes in non-resistance trained males and elite rugby playing position. BMC Genet. 2017, 18, 4. [CrossRef]

89. Yang, L.; Yao, X.; Shen, J.; Sun, G.; Sun, Q.; Tian, X.; Li, X.; Li, X.; Ye, L.; Zhang, Z.; et al. Comparison of revised EWGSOP criteria and four other diagnostic criteria of sarcopenia in Chinese community-dwelling elderly residents. Exp. Gerontol. 2020, 130, 110798. [CrossRef]

90. Bahat, G.; Tufan, A.; Tufan, F.; Kilic, C.; Akpinar, T.S.; Kose, M.; Erten, N.; Karan, M.A.; Cruz-Jentoft, A.J. Cut-off points to identify sarcopenia according to European Working Group on Sarcopenia in Older People (EWGSOP) definition. Clin. Nutr. 2016, 35, 1557-1563. [CrossRef] [PubMed]

91. Yalcin, A.; Aras, S.; Atmis, V.; Cengiz, O.K.; Varli, M.; Cinar, E.; Atli, T. Sarcopenia prevalence and factors associated with sarcopenia in older people living in a nursing home in A nkara T urkey. Geriatr. Gerontol. Int. 2016, 16, 903-910. [CrossRef]

92. Degens, H. Human Ageing: Impact on Muscle Force and Power, in Muscle and Exercise Physiology; Elsevier: Amsterdam, The Netherlands, 2019; pp. 423-432.

93. Witherspoon, D.J.; Wooding, S.; Rogers, A.R.; E Marchani, E.; Watkins, W.S.; A Batzer, M.; Jorde, L.B. Genetic Similarities Within and Between Human Populations. Genetics 2007, 176, 351-359. [CrossRef] [PubMed]

94. De Lima, L.R.A.; Rech, C.R.; Petroski, E.L. Use of bioelectrical impedance for the estimation of skeletal muscle mass in elderly men. Arch. Latinoam. Nutr. 2008, 58, 386-391.

95. Faria, S.L.; Faria, O.P.; Cardeal, M.D.A.; Ito, M.K. Validation Study of Multi-Frequency Bioelectrical Impedance with Dual-Energy X-ray Absorptiometry Among Obese Patients. Obes. Surg. 2014, 24, 1476-1480. [CrossRef] [PubMed]

96. Janssen, I.; Heymsfield, S.B.; Ross, R. Low Relative Skeletal Muscle Mass (Sarcopenia) in Older Persons Is Associated with Functional Impairment and Physical Disability. J. Am. Geriatr. Soc. 2002, 50, 889-896. [CrossRef] [PubMed]

97. Wang, H.; Hai, S.; Cao, L.; Zhou, J.; Liu, P.; Dong, B.-R. Estimation of prevalence of sarcopenia by using a new bioelectrical impedance analysis in Chinese community-dwelling elderly people. BMC Geriatr. 2016, 16, 216. [CrossRef] 